\title{
Toxicological Evaluation of Phytochemical Characterized Aqueous Extract of Wild Dried Lentinus squarrosulus (Mont.) Mushroom in Rats
}

\author{
Eziuche Amadike Ugbogu' ${ }^{1}$, Iroha Emmanuel Akubugwo ${ }^{1}$, Victor Chibueze Ude ${ }^{2}$, James Gilbert ${ }^{1}$ \\ and Blessing Ekeanyanwu' \\ ${ }^{1}$ Department of Biochemistry, Abia State University, Abia State, Nigeria \\ ${ }^{2}$ Department of Medical Biochemistry, College of Medicine Enugu State University of Science and Technology, \\ Enugu, Nigeria
}

\begin{abstract}
Lentinus squarrosulus (Mont.) is an edible wild mushroom with tough fruiting body that belongs to the family Polyporaceae. It is used in ethnomedicine for the treatment of ulcer, anaemia, cough and fever. Recent studies have demonstrated its anticancer, anti-diabetic and antioxidant properties. However, little or no information is available regarding the bioactive components and toxicological study of wild dried L. squarrosulus. Therefore, this study investigated the bioactive components of aqueous extract of boiled wild dried L. squarrosulus and its toxicological effects in rats. The extract of $L$. squarrosulus was subjected to GC-MS analysis. The acute toxicity test was performed by oral administration of a single dose of up to $5,000 \mathrm{mg} / \mathrm{kg}$ extract of L. squarrosulus. In subacute study, the rats were orally administered extract of $L$. squarrosulus at the doses of 500, 1,000 and 1,500 mg/ $\mathrm{kg}$ body weight daily for 14 days. The haematological, lipid profile, liver and kidney function parameters were determined and the histopathology of the liver and kidney were examined. The GC-MS analysis revealed the presence of bioactive compounds; 1-tetradecene, fumaric acid, monochloride, 6-ethyloct-3-yl ester, 9-eicosene, phytol, octahydropyrrolo[1,2-a]pyrazine and 3-trifluoroacetoxypentadecane. In acute toxicity study, neither death nor toxicity sign was recorded. In the sub-acute toxicity study, significant differences $(p<0.05)$ were observed on creatinine, aspartate aminotransferase, alanine aminotransferase, total cholesterol, triglycerides and high-density lipoprotein cholesterol. Whilst no significant differences $(p>0.05)$ were observed on packed cell volume, heamoglobin, red blood cell, white blood cell and alkaline phosphatase, in all the tested doses. No histopathological alterations were recorded. Our findings revealed that aqueous extract of L. squarrosulus may have antimicrobial, antinocieptive and antioxidant properties based on the result of GC-MS analysis. Results of the toxicity test showed no deleterious effect at the tested doses, suggesting that L. squarrosulus is safe for consumption at the tested doses.
\end{abstract}

Key words: Lentinus squarrosulus, Bioactive compound, Toxicity, Haematology, Liver, Kidney

\section{INTRODUCTION}

Mushrooms are increasingly being consumed both in developed and under developed countries due to their nutritional and medicinal values. Today, edible mushrooms are considered as an important remedy for prevention and treatment of diseases (1). Many researchers have reported that most edible mushrooms are therapeutic foods that exhibit numerous biological properties such as antibacterial, anticancer, antiviral activities and antioxidant properties $(2,3)$. Other researchers have also reported that edible mushrooms are rich sources of nutraceuticals $(4,5)$. There
Correspondence to: Eziuche Amadike Ugbogu, Department of Biochemistry, Abia State University, PMB 2000, Uturu, Abia State, Nigeria

E-mail: amasryal@yahoo.com
This is an Open-Access article distributed under the terms of the Creative Commons Attribution Non-Commercial License (http:// creativecommons.org/licenses/by-nc/3.0) which permits unrestricted non-commercial use, distribution, and reproduction in any medium, provided the original work is properly cited. 
are about 200 species of mushroom and only 22 are cultivable, while others are not and Lentinus squarrosulus is among the cultivable mushroom species $(6,7)$. Mushrooms are reported to be more nutritive than vegetables and its nutritive content is comparable to meat, milk and egg $(6,8)$.

Lentinus squarrosulus is an edible wild or cultivated mushroom that belongs to the family Polyporaceae. Wild L. squarrosulus usually grow on decaying deciduous trees in tropical and sub-tropical rainforest such as Nigeria. $L$. squarrosulus is popularly known as 'Ero atakata or ata achicha puanya' in South-Eastern part of Nigeria. In traditional medicine, it is used in treatment of ulcer (9), anaemia, infertility in both men and women (10) and to lower the risk of chronic diseases (11-13). Venkatachalapathi and Paulsamy (14) reported that L. squarrosulus is also utilized in the treatment of common diseases such as cough, fever, and fungal infections while Poompouang and Suksomtip (15) stated that L. squarrosulus is highly appreciated in Thailand because of its curative and tonic characteristics.

Proximate analysis of $L$. squarrosulus has shown high content of protein (9), minerals (potassium, magnesium, calcium, phosphorous and iron) (16), thiamine, riboflavin, folic acid, and dietary fibres with low fat and caloric value (9). The low fat and caloric content signifies that it could be useful as food or essential component of food for hyperlipidemic and diabetic patients (17). Phytochemicals present in fruiting bodies, mycelia and spores include phenolic (gallic acid, catechin, isoquercetin, kaempferol), saponins, flavonoids, tannins, alkaloids, quinolones, terpenes, and anthraquinones $(18,19)$. Other primary metabolites present are peptides, steroids, benzoic derivatives, ascorbic acid, amino acids and oxalic acids $(20,21)$.

L. squarrosulus has been demonstrated to possess some antimicrobial properties against gram positive, gram negative and pathogenic bacteria $(22,23)$. The presence of both the secondary and primary metabolites including the antioxidants in L. squarrosulus has been indicated as the reason for its ability to modulate immunity $(13,24)$; regulate hypertension and hypercholestemia (25), and its anti-oxidative and anticancer properties $(9,13)$. Interestingly, at present mushroom extracts including L. squarrosulus are commercially available as dietary supplement due to their immune modulation and anticancer activity $(26,27)$. Wild mushroom is preferred than artificially cultivated ones in many countries and has been shown to be more nutritious with high medicinal value compare to artificially cultivated ones $(28,29)$. When grown on heavily polluted environment, mushrooms also accumulate high level of hazardous heavy metals such as cadmium and mercury (28). Previous studies by Omar et al. $(9,12)$ reported that $L$. squarrosulus is not toxic and stated that the $\mathrm{LD}_{50}$ is greater than $5 \mathrm{~g} / \mathrm{kg}$ body weight. In both studies, they established that at the doses of $250 \mathrm{mg} / \mathrm{kg}$ and $500 \mathrm{mg} / \mathrm{kg}$ that the extract of L. squarrosulus did not cause any liver damage due to non-significant increase in the activity of liver biomarkers (AST, ALT and ALP) when compared to the control.

Although, there are numerous reports on nutritional constituents, anti-inflammatory, anticancer, anti-diabetic, anticholestamic, anti-ulcer and anti-oxidative properties of wild L. squarrosulus, little or no reports have been published on bioactive components and the toxicity of the aqueous extract. Therefore, this present study evaluates the bioactive components and also toxicity profile of aqueous extract of boiled wild dried L. squarrosulus in rats.

\section{MATERIALS AND METHODS}

Mushroom collection and authentication. Fresh wild L. squarrosulus was collected from its natural habitat in Isiala Ngwa South Local Government Area of Abia State, Nigeria in May 2016 and authenticated by a Mycologist at African Centre for Mushroom Research and Technology Innovation (ACMRTI) with herbarium reference number ACMBRTI00045.

Preparation of the extract. Fresh wild L. squarrosulus was destalked and washed with deionized water before sun drying for 7 days. After sun drying, L. squarrosulus was grinded to powder using electric blender. Exactly $300 \mathrm{~g}$ of the powdered L. squarrosulus were boiled for $30 \mathrm{~min}$ in $1 \mathrm{~L}$ distilled water. The boiled sample was allowed to cool at room temperature and then filtered using Whatman ${ }^{\mathbb{B}}$ Grade No 1 filter paper (Fisher Scientific, Loughborough, UK). The filtrate (aqueous extract) was freeze-dried prior to usage. The extract was later reconstituted in distilled $\mathrm{H}_{2} \mathrm{O}$ to give the required doses of $500,1,000,1,500,2,000$ and $5,000 \mathrm{mg} / \mathrm{kg}$ body weight required for this study.

Gas chromatography-mass spectrometric (GC-MS) analysis. The aqueous extract of wild L. squarrosulus was subjected to GC-MS analysis. The analysis was conducted using Agilent 7890A-5975C GC-MS system. A HP5-column $(30 \mathrm{~m} \times 0.25 \mathrm{~mm} \times 0.25 \mu \mathrm{m})$, operating in electron impact mode at $70 \mathrm{eV}$ was used. The carrier gas was ultra-pure helium at a flow rate of $1.0 \mathrm{~mL} / \mathrm{min}$ and a linear velocity of $37 \mathrm{~cm} / \mathrm{s}$. The injector temperature was set at $250^{\circ} \mathrm{C}$. The initial oven temperature was at $110^{\circ} \mathrm{C}$ which was programmed to increase to $280^{\circ} \mathrm{C}$ at the rate of $10^{\circ} \mathrm{C} / \mathrm{min}$ with a hold time of $7 \mathrm{~min}$ at each increment. Injections of $0.5 \mu \mathrm{L}$ were made in the splitless mode with a split ratio of 10:1. The mass spectrometer was operated in the electron ionization mode at $70 \mathrm{eV}$. The bioactive compounds were identified by direct comparison of the retention time, mass spectral data and fragmentation pattern with those in the National Institute of Standards and Technology library. 
Animal handling. Experimental procedures and animal handling were approved by the Abia State University, Research Ethical Clearance Committee (ABSU/REC/ BMR/0013). Healthy rats weighing between 140 and $180 \mathrm{~g}$ were purchased from animal house of University of Nigeria Nsukka, Nigeria. The rats were transported to Department of Biochemistry, Abia State University, Nigeria and allowed to acclimatize to laboratory conditions for two weeks. The rats were kept under normal standard environmental conditions of temperature $\left(25-28^{\circ} \mathrm{C}\right)$, humidity (35$60 \%)$ and $12 \mathrm{hr} / 12 \mathrm{hr}$ light/darkness cycles. They were also fed ad libitum with standard rat feed and allowed free access to water. Ethical principles of World health Organization good laboratory practice regulations of 1998 and United States guidelines for experimental animals $(30,31)$ were strictly adhered throughout the study.

Acute toxicity test. In accordance to the guideline of Organization for Economic Cooperation and Development (OECD) (32) guideline 423 with little modifications, rats were randomly divided into 5 groups of 12 rats (6 males and 6 females). The male (6) and female (6) rats were kept in different cages for each group. Followed by oral administration of graded single dose of 500, 1,000, 2,000 and $5,000 \mathrm{mg} / \mathrm{kg}$ of aqueous extract of $L$. squarrosulus and the control group received $0 \mathrm{mg} / \mathrm{kg}$ of the $L$. squarrosulus extract. The rats were allowed free access to food and water ad libitum and monitored for a period of $24 \mathrm{hr}$ posttreatment. Within and after the period of $24 \mathrm{hr}$, behavioural changes and signs of toxicity were assessed.

Sub-chronic toxicity study. According to the guidance of Organization for economic cooperation and development (OECD) (33) guideline 407 with slight modifications, twenty four rats were randomly divided into 4 groups of 6 rats per group. The aqueous extract of $L$. squarrosulus were administered orally at doses of $500,1,000,1,500 \mathrm{mg} /$ $\mathrm{kg}$ and the control group received $0 \mathrm{mg} / \mathrm{kg}$ of the L. squarrosulus extract daily for 14 days. The rats were allowed access to food and water ad libitum and weighed daily throughout the period of experiment.

Organ and blood sample collection. At the end of the treatment with aqueous extract of $L$. squarrosulus (14th day), the rats were fasted overnight and sacrificed on the 15 th day of the experiment. Blood samples were collected via cardiac puncture with the help of syringe and needle. The samples for biochemical tests were dispensed into heparinized containers while the samples for haematological analysis were dispensed into ethylenediaminetetraacetic acid (EDTA) containers. The liver, kidneys, heart, lungs and spleen were removed carefully by dissection and the weight of the organs was determined by weighing. Then the organs were fixed in $10 \%(\mathrm{v} / \mathrm{v})$ formalin saline for his- tological studies.

The relative organ weights were calculated using the equation below:

Relative organ weight $=$ Organ weight $(\mathrm{g}) /$ Body weight of rat on sacrificed day $\times 100$.

Haematological and biochemical analysis. Haemoglobin $(\mathrm{Hb})$ level, packed cell volume (PCV), white blood cell (WBC) count, platelets and red blood cell (RBC) indices such as mean corpuscular haemoglobin $(\mathrm{MCH})$, mean corpuscular haemoglobin concentration (MCHC), mean corpuscular volume (MCV) were analysed using the methods described by Bain et al (34). Standard ready-to-use kits from Randox Laboratory Ltd., Co. (Antrim, UK) were used to determine the concentration of liver enzymes (alkaline phosphatase (ALP), alanine aminotransferase (ALT) and aspartate aminotransferase (AST)) and renal function parameters (urea, creatinine, sodium, potassium, chloride and bicarbonate) spectrophotometrically. Other parameters determined spectrophotometrically using standard ready to use kits from Randox Laboratory Ltd., Co. include total cholesterol (TC), triglycerol (TAG), very low density lipoprotein cholesterol (VLDL-C), low density lipoprotein cholesterol (LDL-C), and high density lipoprotein cholesterol (HDL-C). All the biochemical analyses were performed strictly following manufacturer's instructions.

Histological studies. The liver and kidney which were fixed in $10 \%$ formalin after the rats were sacrificed, they were processed routinely and embedded in paraffin wax. Then, the tissues were sectioned to obtain $5 \mu \mathrm{m}$ thickness, stained with haematoxylin and eosin following the method described by Fisher et al (35). The processed sections were finally viewed using light microscope and images obtained.

Statistical analysis. One-way analysis of variance (ANOVA) with the $\mathrm{R}^{\mathrm{TM}}$ Statistic software package, version 3.0.3 (https://cran.r-project.org/src/base/R-3/) and excel package (Microsoft, Washington, DC, USA) were used for statistical analysis. Figures were generated using Graph pad prism version 5.0 Graph Pad Software (San Diego, CA, USA). Tukey test post-hoc was used to identify statistical differences among groups. A $p$-value of $\leq 0.05$ was considered statistically significant.

\section{RESULTS}

The GC-MS analysis of the aqueous extract of $L$. squarrosulus reveals the presence of 15 chemical compounds of which only six out of the 15 identified compounds have known pharmacological activities as shown in Table 1 . The six (6) bioactive compounds with pharmacological activities are; 1-tetradecene, fumaric acid, monochloride, 
Table 1. GC-MS spectral analysis of aqueous extract of Lentinus squarrosulus

\begin{tabular}{|c|c|c|c|c|}
\hline $\mathrm{RT}(\min )$ & Name of the compound & Molecular formula & Molecular weight & Peak area $\%$ \\
\hline 9.430 & 1-Tetradecene & $\mathrm{C}_{14} \mathrm{H}_{28}$ & 196 & 18.46 \\
\hline 9.796 & Fumaric acid, monochloride, 6-ethyloct-3-yl ester & $\mathrm{C}_{14} \mathrm{H}_{23} \mathrm{ClO}_{3}$ & 274 & 1.96 \\
\hline 10.060 & 1-Buten-3-yne, 1-chloro-, (Z)- & $\mathrm{C}_{4} \mathrm{H}_{3} \mathrm{Cl}$ & 86 & 1.27 \\
\hline 12.354 & 1-Buten-3-yne, 1-chloro-, (Z)- & $\mathrm{C}_{4} \mathrm{H}_{3} \mathrm{Cl}$ & 86 & 1.23 \\
\hline 12.480 & 9-Eicosene, $(\mathrm{E})-$ & $\mathrm{C}_{20} \mathrm{H}_{40}$ & 280 & 28.20 \\
\hline 12.778 & Cyclopentanone, 2-(1-methylpropyl) & $\mathrm{C}_{9} \mathrm{H}_{16} \mathrm{O}$ & 140 & 2.76 \\
\hline 13.001 & Acetic acid, dichloro- & $\mathrm{C}_{2} \mathrm{H}_{2} \mathrm{Cl}_{2} \mathrm{O}_{2}$ & 128 & 3.00 \\
\hline 13.464 & Phytol & $\mathrm{C}_{20} \mathrm{H}_{40} \mathrm{O}$ & 296 & 1.28 \\
\hline 13.533 & Cetene & $\mathrm{C}_{16} \mathrm{H}_{32}$ & 224 & 23.05 \\
\hline 13.619 & 1-Buten-3-yne, 2-chloro- & $\mathrm{C}_{4} \mathrm{H}_{3} \mathrm{Cl}$ & 84 & 1.67 \\
\hline 13.733 & Octahydropyrrolo[1,2-a]pyrazine & $\mathrm{C}_{7} \mathrm{H}_{14} \mathrm{~N}_{2}$ & 126 & 2.68 \\
\hline 13.899 & 3-Trifluoroacetoxypentadecane & $\mathrm{C}_{17} \mathrm{H}_{31} \mathrm{~F}_{3} \mathrm{O}_{2}$ & 324 & 2.24 \\
\hline 15.936 & 17-Pentatriacontene & $\mathrm{C}_{35} \mathrm{H}_{70}$ & 490 & 3.49 \\
\hline 16.256 & Carbonic acid, tridecyl 2,2,2-trichloroethyl ester & $\mathrm{C}_{16} \mathrm{H}_{29} \mathrm{Cl}_{3} \mathrm{O}_{3}$ & 374 & 6.18 \\
\hline 16.548 & Bromoacetic acid, pentadecyl ester & $\mathrm{C}_{17} \mathrm{H}_{33} \mathrm{BrO}_{2}$ & 348 & 2.52 \\
\hline
\end{tabular}

Table 2. Structural and pharmacological potentials of major bioactive compounds present in aqueous extract of Lentinus squarrosulus

Compound

6-ethyloct-3-yl ester, 9-eicosene, phytol, octahydropyrrolo[1,2-a]pyrazine, and 3-trifluoroacetoxypentadecane (Table 2).

The rats were assessed for signs of abnormalities before and after acute treatment with varying dosages from 500 to $5,000 \mathrm{mg} / \mathrm{kg}$ of aqueous extract of $L$. squarrosulus after $24 \mathrm{hr}$ and thereafter for 14 days. No death was observed in all the groups (Table 3). No death or sign of toxicity was observed after sub-acute (14 days) administration 500, $1,000,1,500 \mathrm{mg} / \mathrm{kg}$ body weight of aqueous extract of L. squarrosulus. There was also no significant difference $(p>0.5)$ in percentage weight gain and weight of organs in all the groups compared to control (Table 4, Fig. 1).

The result of haematological study as shown in Table 5
Table 3. Acute (oral) toxicity of aqueous dry extract of $L$. squarrosulus mushroom to albino rats after $24 \mathrm{hr}$ of administration

\begin{tabular}{clll}
\hline \hline Group & Dose $(\mathrm{mg} / \mathrm{kg})$ & $\mathrm{D} / \mathrm{T}$ & Signs of toxicity \\
\hline A & $0.25 \mathrm{~mL}\left(\mathrm{H}_{2} \mathrm{O}\right)$ & $0 / 12$ & No toxic effects \\
B & 500 & $0 / 12$ & No toxic effects \\
$\mathrm{C}$ & 1000 & $0 / 12$ & No toxic effects \\
$\mathrm{D}$ & 2000 & $0 / 12$ & No toxic effects \\
E & 5000 & $0 / 12$ & No toxic effects \\
\hline
\end{tabular}

D/T: Number of albino rat deaths/Total number of albino rats used.

demonstrated a non-significant difference $(p>0.5)$ in PVC, $\mathrm{RBC}, \mathrm{MCHC}, \mathrm{MCH}, \mathrm{MCV}, \mathrm{WBC}$, lymphocytes and eosinophil. Significant differences $(p<0.5)$ were observed 
Table 4. Effect of aqueous dry extract of $L$. squarrosulus on the body weight of rats after 14 days of administration

\begin{tabular}{ccccc}
\hline \hline \multirow{2}{*}{ Parameters } & 0 & 500 & 1000 & 1500 \\
\cline { 2 - 5 } & $144.00 \pm 17.39$ & $155.80 \pm 16.45$ & $166.00 \pm 14.61$ & $146.40 \pm 14.61$ \\
\hline Weight at day 0 & $155.60 \pm 24.10$ & $166.00 \pm 16.14$ & $179.60 \pm 16.44$ & $163.20 \pm 11.45$ \\
Weight at day 14 & 11.60 & 10.20 & 13.60 & 16.80 \\
Weight gain (g) & 7.46 & 6.14 & 7.57 & 10.29 \\
Weight gain (\%) & & &
\end{tabular}

Values represent the mean \pm SD for $n=6$.

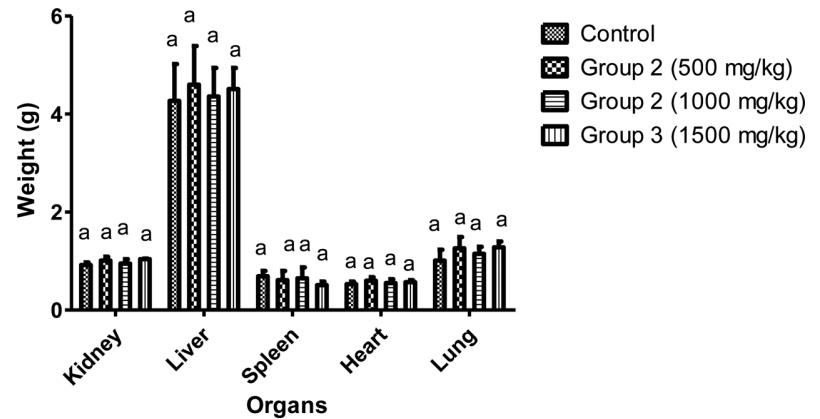

Fig. 1. Effect of aqueous dry extract of $L$. squarrosulus on the organ weight of Wistar rats. Values represent the mean \pm SD for $n=6$. Bars in the same group bearing the same letter of the alphabet (a) are not significantly different $(p>0.05)$. Rats were administered with aqueous dry extract of $L$. squarrosulus (500, 1,000 and $1,500 \mathrm{mg} / \mathrm{kg}$ body weight) for 14 days then, sacrifice and the organ weight measured.

in neutrophil, monocytes and platelets of rats treated with $500,1,000,1,500 \mathrm{mg} / \mathrm{kg}$ body weight of aqueous extract of L. squarrosulus groups compared to control.

In the renal function study, a significant $(p<0.05)$ decrease in $\mathrm{K}^{+}, \mathrm{Na}^{+}$and $\mathrm{Cl}^{-}$were observed on the rats treated with

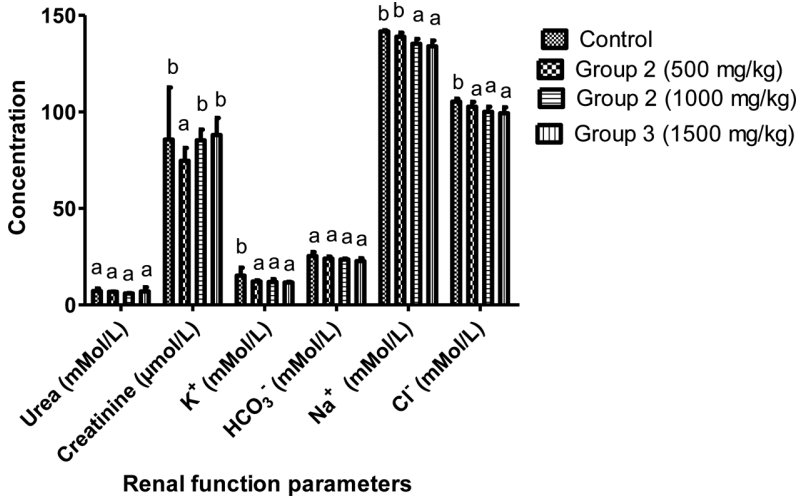

Fig. 2. Effect of aqueous dry extract of $L$. squarrosulus on renal function of Wistar rats. Values represent the mean $\pm S D$ for $n=6$. Bars in the same group bearing the same letter of the alphabet $(a, b)$ are not significantly different $(p>0.05)$. Rats were administered with aqueous dry extract of $L$. squarrosulus $(500,1,000$ and $1,500 \mathrm{mg} / \mathrm{kg}$ body weight) for 14 days then, sacrifice and the renal function parameters measured spectrophotometrically.

aqueous extract of L. squarrosulus (1,000 and 1,500 mg/kg body weight) compared to control group while no changes were observed in urea, creatinine and $\mathrm{HCO}_{3}^{-}$compared to

Table 5. Effect of aqueous dry extract of $L$. squarrosulus on haematological parameters of Wistar rats

\begin{tabular}{|c|c|c|c|c|}
\hline \multirow{2}{*}{ Parameters } & \multicolumn{4}{|c|}{ Dose (mg/kg) } \\
\hline & 0 & 500 & 1000 & 1500 \\
\hline PCV (\%) & $49.67 \pm 0.58^{\mathrm{a}}$ & $53.33 \pm 0.58^{\mathrm{a}}$ & $52.33 \pm 6.03^{\mathrm{a}}$ & $52.00 \pm 2.65^{\mathrm{a}}$ \\
\hline $\mathrm{Hb}(\mathrm{g} / \mathrm{dL})$ & $14.40 \pm 0.52^{\mathrm{a}}$ & $14.07 \pm 0.29^{\mathrm{a}}$ & $14.00 \pm 1.45^{\mathrm{a}}$ & $14.33 \pm 0.57^{\mathrm{a}}$ \\
\hline $\mathrm{RBC}\left(\times 10^{12} / \mathrm{L}\right)$ & $7.94 \pm 0.18^{\mathrm{a}}$ & $8.03 \pm 0.13^{\mathrm{a}}$ & $8.41 \pm 1.13^{\mathrm{a}}$ & $8.09 \pm 0.41^{\mathrm{a}}$ \\
\hline $\mathrm{MCV}(\mathrm{fL})$ & $64.40 \pm 1.57^{\mathrm{a}}$ & $64.70 \pm 0.89^{\mathrm{a}}$ & $62.23 \pm 1.69^{\mathrm{a}}$ & $64.07 \pm 0.40^{\mathrm{a}}$ \\
\hline $\mathrm{MCH}(\mathrm{pg})$ & $18.13 \pm 0.23^{\mathrm{a}}$ & $17.50 \pm 0.17^{\mathrm{a}}$ & $16.70 \pm 0.82^{\mathrm{a}}$ & $17.73 \pm 0.45^{\mathrm{a}}$ \\
\hline $\mathrm{MCHC}(\mathrm{g} / \mathrm{dL})$ & $28.20 \pm 0.53^{\mathrm{a}}$ & $27.10 \pm 0.56^{\mathrm{a}}$ & $26.83 \pm 0.61^{\mathrm{a}}$ & $27.67 \pm 0.64^{\mathrm{a}}$ \\
\hline $\mathrm{WBC}\left(\times 10^{9} / \mathrm{L}\right)$ & $12.93 \pm 6.64^{\mathrm{a}}$ & $10.27 \pm 1.82^{\mathrm{a}}$ & $12.50 \pm 1.32^{\mathrm{a}}$ & $12.23 \pm 3.41^{\mathrm{a}}$ \\
\hline Neutrophil (\%) & $3.33 \pm 0.58^{\mathrm{a}}$ & $7.33 \pm 3.21^{\mathrm{b}}$ & $10.00 \pm 2.00^{c}$ & $7.33 \pm 0.58^{\mathrm{b}}$ \\
\hline Lymphocyte (\%) & $86.33 \pm 2.31^{\mathrm{a}}$ & $83.33 \pm 6.66^{\mathrm{a}}$ & $82.00 \pm 2.00^{\mathrm{a}}$ & $81.67 \pm 4.51^{\mathrm{a}}$ \\
\hline Eosinophil (\%) & $2.33 \pm 1.15^{\mathrm{a}}$ & $2.67 \pm 0.58^{\mathrm{a}}$ & $3.67 \pm 1.53^{\mathrm{a}}$ & $2.67 \pm 1.15^{\mathrm{a}}$ \\
\hline Basophil (\%) & $1.00 \pm 0.00^{\mathrm{a}}$ & $1.67 \pm 1.15^{\mathrm{a}}$ & $1.00 \pm 0.00^{\mathrm{a}}$ & $1.67 \pm 1.15^{\mathrm{a}}$ \\
\hline Monocytes (\%) & $7.00 \pm 1.00^{\mathrm{b}}$ & $5.00 \pm 2.00^{\mathrm{b}}$ & $3.33 \pm 1.53^{\mathrm{a}}$ & $6.67 \pm 3.06^{\mathrm{b}}$ \\
\hline Platelet $\left(\times 10^{9} / \mathrm{L}\right)$ & $784.33 \pm 54.01^{\mathrm{a}}$ & $900.33 \pm 122.17^{\mathrm{c}}$ & $816.67 \pm 123.66^{\mathrm{b}}$ & $936.00 \pm 47.70^{c}$ \\
\hline
\end{tabular}

Values represent the mean \pm SD for $n=6$. Values in the same row bearing the same letter of the alphabet $(a, b, c)$ are not significantly different $(p>0.05)$. PVC, packed cell volume; Hb, Hemoglobin; RBC, red blood cell; MCV, mean corpuscular volume; MCH, mean corpuscular haemoglobin; MCHC, mean corpuscular hemoglobin concentration;WBC, white blood cell (WBC). 


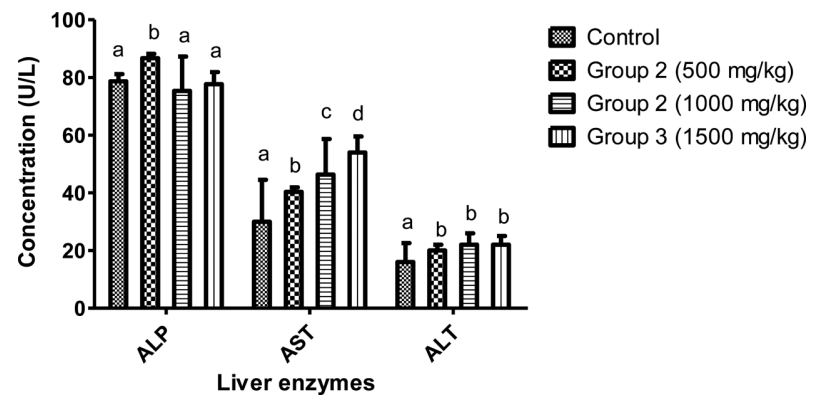

Fig. 3. Effect of aqueous dry extract of $L$. squarrosulus on hepatic enzymes of Wistar rats. Values represent the mean \pm SD for $n=6$. Bars in the same group bearing the same letter of the alphabet $(a, b, c, d)$ are not significantly different from each other $(p>0.05)$. Rats were administered with aqueous extract of $L$. squarrosulus (500, 1,000 and $1,500 \mathrm{mg} / \mathrm{kg}$ body weight) for 14 days then, sacrifice and the liver enzymes measured spectrophotometrically.

control (Fig. 2).

ALT and AST significantly increased in rats treated with aqueous extract of L. squarrosulus (500, 1,000 and 1,500 $\mathrm{mg} / \mathrm{kg}$ body weight) compared to control. In addition, ALP showed no significant change $(p>0.05)$ with values ranging from $75.33 \pm 11.93$ to $86.67 \pm 1.53 \mathrm{U} / \mathrm{L}$ (Fig. 3).

Lipid profile analysis showed a significant $(p<0.05)$ decrease in cholesterol, triglycerol and LDL-C in all the groups treated with aqueous extract of L. squarrosulus compared to control group. Whilst, HDL-C showed no significant $(p>0.05)$ change compared to control group with value ranging from $0.95-1.38 \mathrm{mMol} / \mathrm{L}$ (Fig. 4). The histological studies of the rat's liver and kidney showed no observable danger or changes as shown in (Fig. 5, 6).

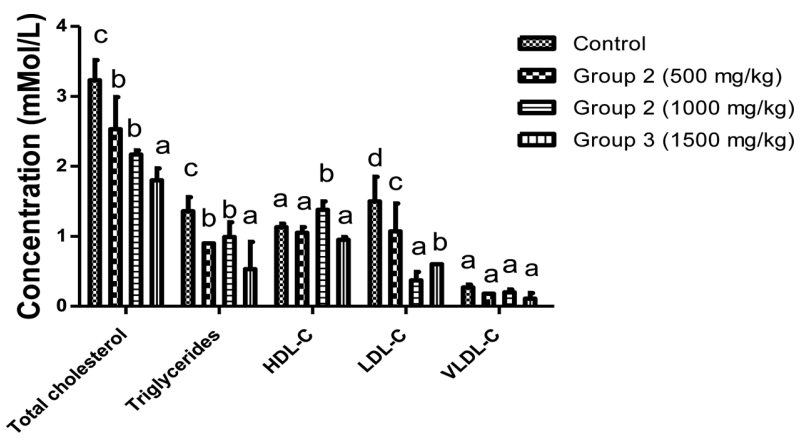

\section{Lipid profile}

Fig. 4. Effect of aqueous dry extract of $L$. squarrosulus on the lipid profile of Wistar rats. Values represent the mean \pm SD for $n=6$. Bars in the same group bearing the same letter of the alphabet $(a, b, c, d)$ are not significantly different $(p>0.05)$. Rats were administered with aqueous dry extract of $L$. squarrosulus $(500,1,000$ and $1,500 \mathrm{mg} / \mathrm{kg}$ body weight) for 14 days then, sacrifice and the lipid profile determined spectrophotometrically.

\section{DISCUSSION}

The GC-MS analysis of the aqueous extract of $L$. squarrosulus revealed six bioactive compounds with pharmacological activities; 1-tetradecene has anti-tuberculosis activity (36). Fumaric acid, monochloride, 6-ethyloct-3-yl ester, is used for treatment of psoriasis, phytol has antinociceptive and antioxidant effects (37), octahydropyrrolo[1,2-a]pyrazine, has antioxidant property (38) and 3-trifluoroacetoxypentadecane exhibits anti-nephrotoxic and antioxidant properties (39) (Table 2). Omar et al. (12) reported that extract of $L$. squarrosulus has antioxidant properties, this may be due to the presence of phytol, octahydropyr-
(A)

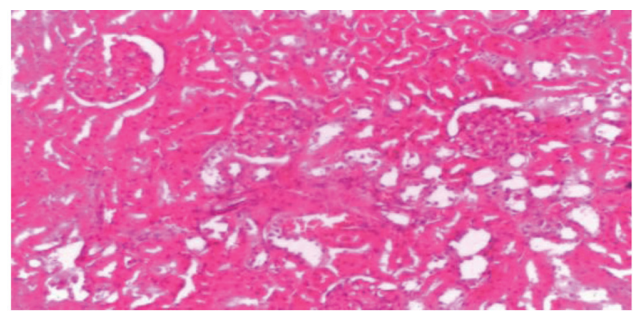

(C)

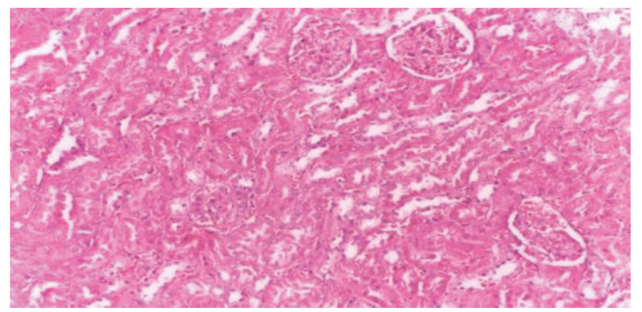

(B)

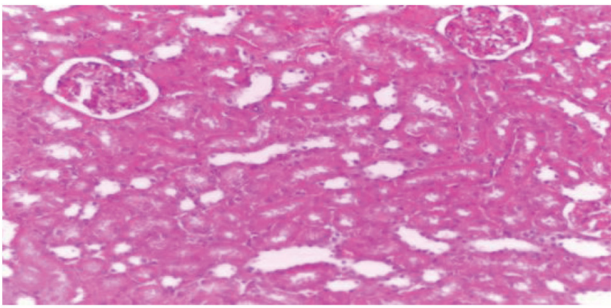

(D)

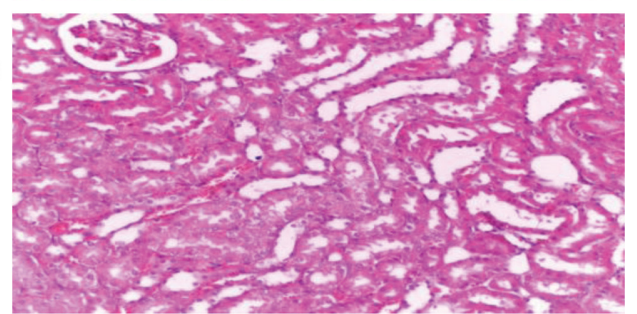

Fig. 5. Micrographs of the kidney sections obtained from untreated (control) and treated Wistar rats with various doses of aqueous dry extract of L. squarrosulus. Haematoxylin and eosin staining (H\&E), Magnification (40X). (A), control (B), Wistar rats treated with $500 \mathrm{mg} / \mathrm{kg}$ aqueous dry extract of $L$. squarrosulus (C), Wistar rats treated with $1,000 \mathrm{mg} / \mathrm{kg}$ aqueous dry extract of (D), Wistar rats treated with $1,500 \mathrm{mg} / \mathrm{kg}$ extract of $L$. squarrosulus. 

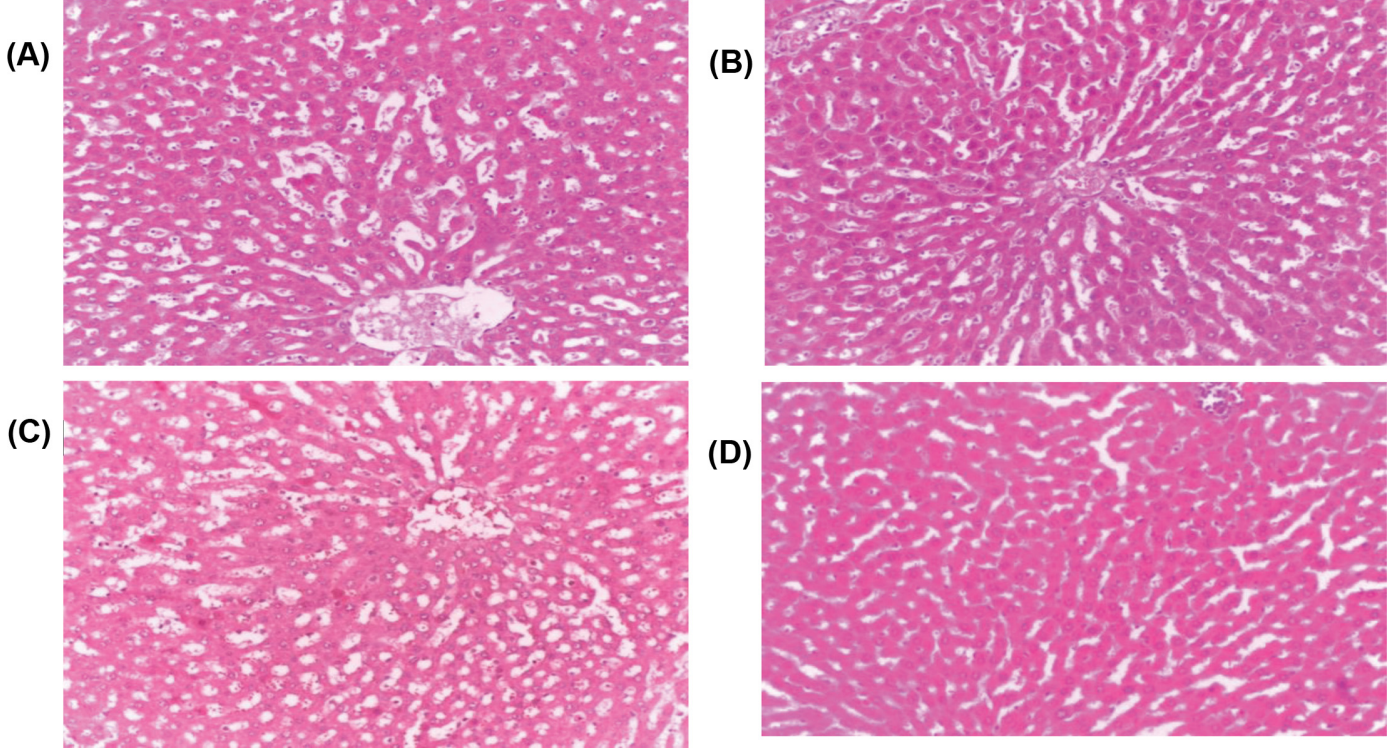

Fig. 6. Micrographs of the liver sections obtained from untreated (control) and treated Wistar rats with various doses of aqueous dry extract of $L$. squarrosulus. Haematoxylin and eosin staining (H\&E), Magnification (40X). (A), control (B), Wistar rats treated with $500 \mathrm{mg} / \mathrm{kg}$ aqueous dry extract of $L$. squarrosulus (C), Wistar rats treated with $1,000 \mathrm{mg} / \mathrm{kg}$ extract of $L$. squarrosulus (D), wistar rats treated with $1,500 \mathrm{mg} / \mathrm{kg}$ extract of $L$. squarrosulus.

rolo[1,2-a]pyrazine, and 3-trifluoroacetoxypentadecane in the extract. The alcoholic extract of $L$. squarrosulus exhibits antimicrobial activity against the gram positive and gram negative microorganisms and antifungal activity comparable to antifungal drug like ketoconazole $(15,23)$. This antimicrobial activity may be because of the presence of 9Eicosene in the extract (40).

The acute toxicity study of aqueous extract of $L$. squarrosulus $(500,1,000,2,000$ and $5,000 \mathrm{mg} / \mathrm{kg}$ body weight) demonstrated no mortality, behavioural changes or toxicity signs. The administration of aqueous extract of $L$. squarrosulus up to $5,000 \mathrm{mg} / \mathrm{kg}$ body weight via oral route did not kill or cause the death of $50 \%$ of the rats. This is an indication that the $\mathrm{LD}_{50}$ of $L$. squarrosulus is greater than $5,000 \mathrm{mg} / \mathrm{kg}$. According to Organization for economic cooperation and development (OECD) (32), L. squarrosulus extract could be assigned as class 5 and thus considered as safe and non-toxic because in acute toxicity test, $\mathrm{LD}_{50}$ above $5,000 \mathrm{mg} / \mathrm{kg}$ is considered as non-toxic substance.

In sub-acute toxicity study, Wistar rats revealed no significant difference in body weight (Table 4 , thus no adverse effect in body weight following oral administration of aqueous extract of $L$. squarrosulus $(500,1,000,1,500 \mathrm{mg} /$ $\mathrm{kg}$ body weight) for 14 days. Changes in body weight and organ weight are often employed in assessing the possible harmful effect of potentially toxic chemicals and pharmaceutical substances (41). All the rats in each group demonstrated optimal weight increase across.

Bone marrow is a known organ for haematopoietic processes and a target organ for toxic compound (42). Blood is very pivotal in physiological, nutritional and pathological status of vertebrates and its assessment for toxicity is very essential. Haematological parameters are very sensitive and are useful for predicting the toxicological and pathological effect of potentially toxic substances in human and animals $(41,42)$. Although, there were significant differences $(p<0.05)$ in neutrophil, monocyte and platelets, the obtained result of haematological parameters (Table 5) were within the standard acceptable reference range $(43,44)$, for all the parameters suggesting that aqueous extract of $L$. squarrosulus had no negative effect on the bone marrow and immune system in all the studied dosage.

Data from serum biochemical parameters are usually used to assess the impact of toxic substances in the organs such as liver and kidney (41). Cellular damage, tissue necrosis and cardiovascular diseases lead to increase in AST and ALT in the serum $(45,46)$. The ALP is often used to assess plasma membrane integrity and its high level in serum is an indication of plasma membrane damages. High level of ALP is usually observed in liver damage, myocardial infarction and cancer (45). Both AST and ALT are markers of integrity and function of liver and heart and are released into the blood from damaged liver. In this study, there were no detrimental effects observed in ALP. The liver biomarkers (AST and ALT) were elevated $(p<0.05)$ after administration of aqueous extract $L$. squarrosulus for 14 days but these changes were within the standard acceptable normal laboratory reference range (44). Additionally, no lesions or pathological changes were observed in the histopathology of the liver, which is an indication that the liver was not 
deleteriously impaired (Fig. 6). This may be due to nontoxic effect of the bioactive compounds to the rats (47). However, the observable significant increase in AST and ALT is an indication that higher doses greater than 1,500 $\mathrm{mg} / \mathrm{kg}$ body weight may cause liver damage.

Increase in serum level of creatinine, urea and electrolytes such as sodium, chloride, bicarbonate, potassium and inorganic phosphate has been shown as a reliable indicator of renal malfunction (41). This study demonstrated nonsignificant difference $(p>0.05)$ in urea, creatinine and electrolytes except group administered with $500 \mathrm{mg} / \mathrm{kg}$ body weight including potassium and sodium ion which were slightly lower but are still within the standard reference range for rat experiments (43). Hence, administration of aqueous extract L. squarrosulus (500, 1,000 and $1,500 \mathrm{mg} / \mathrm{kg}$ body weight) has no adverse effect on the renal function of the rats. The histological study of the kidney did not reveal any adverse effect on the microscopic changes or morphology of the kidney which supports the non-toxic effect of $L$. squarrosulus on kidney (Fig. 5).

Total cholesterol, triglycerides and LDL-C were decreased significantly $(p<0.05)$ compared to the control group with group administered with $1,500 \mathrm{mg} / \mathrm{kg}$ body weight showing more than $50 \%$ decrease. The result corroborates with the findings of Kanagasabapathy et al. (48) who reported that Pleurotus sajor-caju (Fr.) Singer mushroom decreased serum total cholesterol and LDL-C level suggesting that $L$. squarrosulus may have the potential to regulate hyperlipidaemia. However, non dose dependent increase in triglyceride was observed in rats that received $1,000 \mathrm{mg} / \mathrm{kg}$ extract when compared to the rats that received 500 and $1,500 \mathrm{mg} / \mathrm{kg}$. This increase may not be treatment-related.

In conclusion, L. squarrosulus is non-toxic and could be used as a source of nutrients and in ethnomedicine without any detrimental effect at the tested doses. This study also established that there were dose-dependent significant increase in the liver biomarkers (AST and ALT) suggesting that increase in doses higher than $1,500 \mathrm{mg} / \mathrm{kg}$ may cause liver damage.

In this study, we recommend that the expected consumption of L. squarrosulus per individual in a normal meal should not exceed $1,500 \mathrm{mg} / \mathrm{kg}$ body weight; this recommendation is based on the dose-dependent significant increase observed in the liver biomarkers (AST and ALT).

\section{ACKNOWLEDGMENTS}

The authors would like to thank Professor E. U. Ikonne, the Vice Chancellor of Abia State University and his management team for providing favourable research environment to carry out this work. Furthermore, the authors thank Professor A.Z.M. Salem for his support and technical assistance.

This research was funded by Tertiary Education Trust
Fund Institutional Base Research Grant (TETFUND/ ABSU/RP/2016/038) from Abia State University, Uturu Nigeria.

\section{CONFLICT OF INTEREST}

Authors declare that they have no competing interests and are responsible for the content and data of this manuscript.

Received July 29, 2018; Revised August 26, 2018; Accepted October 4, 2018

\section{REFERENCES}

1. Kidd, P.M. (2000) The use of mushroom glucans and proteoglycans in cancer treatment. Altern. Med. Rev., 5, 4-27.

2. Garcia-Lafuente, A., Moro, C., Villares, A., Guillamón, E., Rostagno, M.A., D'Arrigo, M. and Martínez, J.A. (2011) Mushrooms as a source of anti-inflammatory agents. Am. J. Community Psychol., 48, 125-141.

3. Schillaci, D., Arizza, V., Gargano, M.L. and Venturella, G. (2013) Antibacterial activity of mediterranean oyster mushrooms, species of genus pleurotus (higher basidiomycetes). Int. J. Med. Mushrooms, 15, 591-594.

4. Ribeiro, B., Valentao, P., Baptista, P., Seabra, R.M. and Andrade, P.B. (2007) Phenolic compounds, organic acids profiles and antioxidative properties of beefsteak fungus (Fistulina hepatica). Food Chem. Toxicol., 45, 1805-1813.

5. Ghate, S.D. and Sridhar, K.R. (2017) Bioactive potential of Lentinus squarrosulus and Termitomyces clypeatus from the Southwestern region of India. Indian J. Nat. Prod. Resour., 8, 120-131.

6. Kirbağ, S. and Akyüz, M. (2010) Nutritive value of edible wild and cultured mushrooms. Turkish J. Biol., 34, 97-102.

7. De Leon, A.M., Guinto, L.J.Z.G., De Ramos, P.D.V. and Kalaw, S.P. (2017) Enriched cultivation of Lentinus squarrosulus (Mont.) singer: a newly domesticated wild edible mushroom in the Philippines. Mycosphere, 8, 615-629,

8. Ayaz, F.A., Chuang, L.T., Torun, H., Colak, A, Sesli, E., Presley, J., Smith, B.R. and Glew, R.H. (2011) Fatty acid and amino acid compositions of selected wild-edible mushrooms consumed in Turkey. Int. J. Food Sci. Nutr., 62, 328335.

9. Omar, N.A.M., Abdullah, N., Kuppusamy, U.R., Abdulla, M.A. and Sabaratnam, V. (2011) Nutritional composition, antioxidant capacity and antiulcer potential of Lentinus squarrosulus (Mont.) Mycelia extract. Evid. Based Complement. Alternat. Med., 2011, 539356.

10. Okigbo, R.N. and Nwatu, C.M. (2015) Ethnostudy and usage of edible and medicinal mushrooms in some parts of Anambra State, Nigeria. Nat. Resour., 6, 79-89.

11. Oyetayo, O.V. (2011) Medicinal uses of mushrooms in Nigeria: towards full and sustainable exploitation. Afr. J. Tradit. Complement Altern. Med., 8, 267-274.

12. Omar, N.A.M., Sumaiyah, Abdullah, N.A., Kuppusamy, U.R., Abdulla, M.A. and Sabaratnam, V. (2015) Lentinus squarrosulus (Mont.) mycelium enhanced antioxidant status 
in rat model. Drug Des. Devel. Ther., 9, 5957.

13. Lau, B.F. and Abdullah, N. (2017) Bioprospecting of Lentinus squarrosulus Mont., an underutilized wild edible mushroom, as a potential source of functional ingredients: a review. Trends Food Sci. Technol., 61, 116-131.

14. Venkatachalapathi, A. and Paulsamy, S. (2016) Exploration of wild medicinal mushroom species in Walayar valley, the Southern Western Ghats of Coimbatore District Tamil Nadu. Mycosphere, 7, 118-130.

15. Poompouang, S. and Suksomtip, M. (2016). Isolation and characterization of an antifungal peptide from fruiting bodies of edible mushroom Lentinus squarrosulus Mont. Malays. J. Microbiol., 12, 43-49.

16. Anno, A.H.F., Konan, H.K., Kouadio, J.P.E.N., Due, E.A. and Kouame, L.P. (2016) Chemical composition and nutritional value of two edible mushrooms from three regions of Cote d'Ivoire. J. Basic Appl. Res., 2, 119-125.

17. Ng, S.H., Mohd Zain, M.S., Zakaria, F., Wan Ishak, W.R. and Wan Ahmad, W.A.N. (2015) Hypoglycemic and antidiabetic effect of Pleurotus sajor-caju aqueous extract in normal and streptozotocin-induced diabetic rats. Biomed. Res. Int., 2015, 214918.

18. Attarat, J. and Thamisak, R. (2014) Anticancer PSP and phenolic compounds in Lentinus squarrosulus and Lentinus polychrous in The 5th International Conference on Natural Products for Health and Beauty. pp. 263-267.

19. Obodai, M., Ferreira, I.C.F.R., Fernandes, A., Barros, L., Mensah, D.L.N., Dzomeku, M., Urben, A.F., Prempeh, J. and Takli, R.K. (2014) Evaluation of the chemical and antioxidant properties of wild and cultivated mushrooms of Ghana. Molecules, 19, 19532-19548.

20. Ademola, I.O. and Odeniran, P.O. (2017) Novel trypanocide from an extract of Pleurotus sajor-caju against Trypanosoma congolense. Pharm. Biol., 55, 132-138.

21. Valverde, M.E., Hernández-Pérez, T. and Paredes-Lopez, O. (2015) Edible mushrooms: Improving human health and promoting quality life. Int. J. Microbiol., 2015, 376387.

22. Ayodele, S.M. and Idoko, M.E. (2011) Antimicrobial activities of four wild edible mushrooms in Nigeria. Int. J. Food Sci. Nutr., 2, 55-58.

23. Borokini, F., Lajide, L., Olaleye, T., Boligon, A., Athayde, M. and Adesina, I. (2016) Chemical profile and antimicrobial activities of two edible mushrooms (Termitomyces robustus and Lentinus squarrosulus). J. Microbiol. Biotechnol. Food Sci., 5, 416-423.

24. Minato, K.-I. (2010) Mushrooms: immunomodulating activity and role in health promotion in Dietary Components and Immune Function. Springer, pp. 529-539.

25. Alam, N., Amin, R., Khan, A., Ara, I., Shim, M.J., Lee, M.W. and Lee, T.S. (2008) Nutritional Analysis of Cultivated Mushrooms in Bangladesh - Pleurotus ostreatus, Pleurotus sajor-caju, Pleurotus florida and Calocybe indica. Mycobiology, 36, 228-232.

26. Barros, L., Ferreira, M.-J., Queiros, B., Ferreira, I.C. and Baptista, P. (2007) Total phenols, ascorbic acid, $\beta$-carotene and lycopene in Portuguese wild edible mushrooms and their antioxidant activities. Food Chem., 103, 413-419.

27. Guillamón, E., García-Lafuente, A., Lozano, M., Rostagno, M.A., Villares, A. and Martínez, J.A. (2010) Edible mush- rooms: role in the prevention of cardiovascular diseases. Fitoterapia, 81, 715-723.

28. Kalač, P. (2013) A review of chemical composition and nutritional value of wild-growing and cultivated mushrooms. J. Sci. Food Agric., 93, 209-218.

29. Mattila, P., Lampi, A.-M., Ronkainen, R., Toivo, J. and Piironen, V. (2002) Sterol and vitamin D2 contents in some wild and cultivated mushrooms. Food Chem., 76, 293-298.

30. Care Animal Use Committee (1998) Guidelines for the capture, handling, and care of mammals as approved by the American Society of Mammalogists. J. Mammal., 79, 14161431.

31. National research council (NRC) (2010) Guide for The Care and Use of Laboratory Animals, National Academies Press.

32. Organization for economic cooperation and development (OECD) (2001) Guideline 423: Acute Oral Toxicity- Acute Toxic Class Method. 470 adopted by the council on 17th, December 2001.

33. Organization for economic cooperation and development (OECD) (1995) Guideline 407: Repeated-Dose 28-Day Oral Toxicity Study in Rodents. 468 adopted by the council on 27th, July 1995.

34. Bain, B.J., Bates, I. and Laffan, M.A. (2016) Dacie and Lewis Practical Haematology, Elsevier Health Sciences.

35. Fisher, D.I., Safrany, S.T., Strike, P., McLennan, A.G. and Cartwright, J.L. (2002) Nudix hydrolases that degrade dinucleoside and diphosphoinositol polyphosphates also have 5phosphoribosyl 1-pyrophosphate (PRPP) pyrophosphatase activity that generates the glycolytic activator ribose 1,5-bisphosphate. J. Biol. Chem., 277, 47313-47317.

36. Srivastava, S.K. and Singh, S.V. (2004) Cell cycle arrest, apoptosis induction and inhibition of nuclear factor kappa B activation in anti-proliferative activity of benzyl isothiocyanate against human pancreatic cancer cells. Carcinogenesis, 25, 1701-1709.

37. Santos. C.C.M.P., Salvadori, M.S., Mota, V.G., Costa, L.M., de Almeida, A.A.C., de Oliveira, G.A.L., Costa, J.P., de Sousa, D.P., de Freitas, R.M. and de Almeida, R.N. (2013) Antinociceptive and antioxidant activities of phytol in vivo and in vitro models. Neuroscience Journal, 2013, 949452.

38. Ser, H.L., Palanisamy, U.D., Yin, W.F., Abd Malek, S.N., Chan, K.G., Goh, B.H. and Lee, L.H. (2015) Presence of antioxidative agent, Pyrrolo[1,2-a]pyrazine-1,4-dione, hexahydro- in newly isolated Streptomyces mangrovisoli sp. nov. Front. Microbiol., 6, 854.

39. Hussein, J.H., Hadi, M.Y. and Hameed, I.H. (2016) Study of chemical composition of Foeniculum vulgare using Fourier transform infrared spectrophotometer and Gas chromatography - mass spectrometry. J. Pharmacognosy Phytother., 8, 60-89.

40. Dalli, A.K., Saha, G. and Chakraborty, U. (2007) Characterization of antimicrobial compounds from a common fern, Pteris biaurita. Indian J. Exp. Biol., 45, 285-290.

41. Kong, B.H., Tan, N.H., Fung, S.Y. and Pailoor, J. (2016) Sub-acute toxicity study of tiger milk mushroom Lignosus tigris Chon S. Tan Cultivar E sclerotium in Sprague Dawley rats. Front. Pharmacol., 7, 246.

42. Kifayatullah, M., Mustafa, M.S., Sengupta, P., Sarker, M.M.R., Das, A. and Das, S.K. (2015) Evaluation of the 
acute and sub-acute toxicity of the ethanolic extract of Pericampylus glaucus (Lam.) Merr. in BALB/c mice. J. Acute Dis., 4, 309-315.

43. Matsuzawa, T. and Inoue, H. (1998) Biological Reference Data on CD (SD) IGS Rats-1998: CD (SD) IGS Study Group.

44. Granados-Echegoyen, C., Perez-Pacheco, R., AlexanderAguilera, A., Lagunez-Rivera, L., Alonso-Hernandez, N. and Chairez-Martinez, E.J (2015) Effects of aqueous and ethanol extract of dried leaves of Pseudocalymma alliaceum (Bignonaceae) on haematological and biochemical parameters of Wistar rats. Asian. Pac. J. Reprod., 4, 129-134.

45. Adeyemi, O.T., Osilesi, O., Adebawo, O.O., Onajobi, F.D., Oyedemi, S.O. and Afolayan, A. (2015) Alkaline phosphatase (ALP), aspartate aminotransferase (AST) and alanine aminotransferase (ALT) Activities in selected tissues of rats fed on processed atlantic horse mackerel (Trachurus tra- churus). Adv. Biosci. Biotechnol., 6, 139.

46. Ioannou, G.N., Weiss, N.S., Boyko, E.J., Mozaffarian, D. and Lee, S.P. (2006) Elevated serum alanine aminotransferase activity and calculated risk of coronary heart disease in the United States. Hepatology, 43, 1145-1151.

47. Nurul, S.A.S., Hazilawati, H., Mohd, R.S., Mohd, F.H.R., Noordin, M.M. and Norhaizan, E. (2018). Subacute oral toxicity assesment of ethanol extract of Mariposa christia vespertilionis leaves in male Sprague Dawley rats. Toxicol. Res., 34, 85-95.

48. Kanagasabapathy, G., Malek, S.N.A., Mahmood, A.A., Chua, K.H., Vikineswary, S. and Kuppusamy, U.R. (2013) Betaglucan-rich extract from Pleurotus sajor-caju (Fr.) Singer prevents obesity and oxidative stress in C57BL/6J mice fed on a high-fat diet. Evid. Based Complement. Alternat. Med., 2013, 185259 . 